\title{
To study the effect of hydroxyurea on transcranial doppler in patients with sickle cell anemia
}

\author{
Phuljhele S. ${ }^{1}$, Pandey P. ${ }^{2 *}$, Banjare R. ${ }^{3}$ \\ DOI: https://doi.org/10.17511/ijpr.2020.i03.04 \\ 1 Sharja Phuljhele, Professor and Head of Department, Department of Pediatrics, Pt. Jawaharlal Nehru Memorial Medical College, and Dr. \\ B.R. A. M. H, Raipur, Chhattisgarh, India. \\ 2* Prankur Pandey, Assistant Professor, Department of Pediatrics, Pt. Jawaharlal Nehru Memorial Medical College, and Dr. B.R. A. M. H, \\ Raipur, Chhattisgarh, India. \\ 3 Rajesh Banjare, Post-Graduate, Department of Pediatrics, Pt. Jawaharlal Nehru Memorial Medical College, and Dr. B.R. A. M. H, Raipur, \\ Chhattisgarh, India.
}

Background: The estimated rate of prevalence of SCD in the population of Chhattisgarh is about 10 to $15 \%$ of which about 1 to $1.27 \%$ are likely to be sufferers and the rest carriers. The frequency of stroke in SCD is estimated at 0.61 per 100 patients per year. TCD is a valuable screening test in many clinical conditions such as SCD, to identify the patients at risk of stroke. An abnormally high blood speed is an indicator of a narrowed cerebral blood vessel and/or increased blood volume and a warning marker of high risk for stroke. Methods: This was a prospective comparative crosssectional observational hospital based study, conducted over a period of 17 months (July 2016 to November 2017) in the Department Of Pediatrics and Radiodiagnosis, Dr. B.R.A.M.H, Raipur (C.G.).Children between 2 to 14 years diagnosed as SCD SS who were receiving long term (>6months) HU(hydroxyurea) treatment (cases) - HU group, and those who had never received this treatment (control) - HU naïve group, were enrolled. Results: The total number of children enrolled in the present study was 120 , out of which 40 were cases and 80 were controls. The mean blood flow velocity of cases was significantly lower than controls. Among cases and controls maximum mean blood flow velocity was found in Left MCA followed by Right MCA. In addition to this, it was also found that there was no significant interhemispheric difference in both group. ( $p$-value more than 0.05). Conclusion: The mean blood flow velocity in the HU group and HU naïve group was within the normal range $(<170 \mathrm{~cm} / \mathrm{sec})$, as per STOP criteria. The mean blood flow velocity in patients who were on the HU group was found to be significantly lower than the HU naïve group.

Keywords: Stroke in SSD, Transcranial doppler, Risk for stroke, HU-hydroxyurea

\section{Corresponding Author}

Prankur Pandey, Assistant Professor, Department of Pediatrics, Pt. Jawaharlal Nehru Memorial Medical College, and Dr. B.R. A. M. H, Raipur, Chhattisgarh, India.

Email: prankurpandey@gmail.com

\section{How to Cite this Article}

Phuljhele S, Pandey P, Banjare R. To study the effect of hydroxyurea on transcranial doppler in patients with sickle cell anemia. Pediatric Rev Int J Pediatr Res. 2020;7(3):136-141.

Available From

https://pediatrics.medresearch.in/index.php/ijpr/arti cle/view/574
To Browse

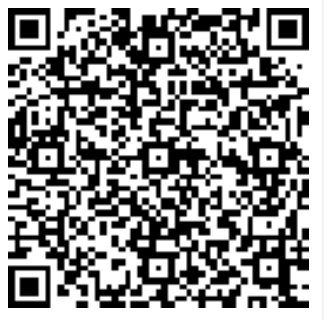

Manuscript Received 2020-03-07

Conflict of Interest No
Review Round 1 2020-03-17

Funding $\mathrm{Nil}$

Review Round 2
$2020-03-22$
Ethical Approval
Yes

Review Round 2

Yes
Review Round 3

Plagiarism X-checker $5 \%$
Accepted 2020-03-27

Note

(C) 2020 by Sharja Phuljhele, Prankur Pandey, Rajesh Banjare and Published by Siddharth Health Research and Social Welfare Society. This is an Open Access article licensed under a Creative Commons Attribution 4.0 International License https://creativecommons.org/licenses/by/4.0/ unported [CC BY 4.0]. 


\section{Introduction}

Sickle Cell disorders are a group of inherited genetic disorders and a major public health problem in Chhattisgarh. These disorders can be transmitted from one generation to the next through the Mendelian recessive type of inheritance. The public health implications of sickle cell disorders are significant. This impact on human health may be assessed against the yardsticks of infant mortality, under-five mortality, and maternal mortality. However, complete curative therapy for Sickle Cell Disorders is not available in any system of Medicine. Symptomatic and supportive treatment is the only mainstay [1-8].

Stroke is a serious complication of sickle cell disease. The majority of strokes are ischemic events caused by stenosis of large cerebral arteries.' Stroke generally occurs without warning and cause significant long term neurologic sequelae in at least $50 \%$ of cases.Chronic transfusion therapy for children who suffer stroke ecreases the recurrent stroke rate from $90 \%$ to less than $10 \%$ [1-8].

TCD is a valuable screening test in many clinical conditions such as $S C D$, to identify the patients at risk of stroke. An abnormally high blood speed is an indicator of a narrowed cerebral blood vessel and/or increased blood volume and a warning marker of high risk for stroke. Regular blood transfusion and treatment with Hydroxyurea can significantly reduce the incidence of stroke in children with SCD who are found to be at high risk of stroke based on abnormal TCD findings. Previous finding has demonstrated that routine TCD screening test in children with SCD can indicate the high risk group and is useful in recommending the initiation of regular blood transfusion or alternatively use of hydroxyurea.Our patients rarely complained of headache and limb weakness. This studywas done out of curiosity to see whether our patients differed from patients elsewhere. The present study aimed, at measuring and comparing the TCD flow velocity in children of 2 years to 14 yrs with SCA SS with and without hydroxyurea [9-12].

\section{Methods}

A cross sectional study was performed at the Department of Pediatrics, Dr. B.R Ambedkar Hospital, Raipur, Chattisgarh, India between July 2016 and November 2017. The study protocol was approved by the Institutional Ethics Committee and Scientific Committee.
Inclusion criteria: Children between 2 to 14 years diagnosed as SCD SS who were receiving long term (>6months) HU treatment (cases) - HU group, and those who had never received this treatment (control) - HU naïve group, were enrolled.

Exclusion criteria: Sickle cell patients who had received recent blood transfusions, had a painful crisis, fever, infections, h/o major head injury, h/o seizure disorder requiring anticonvulsant therapy, and who had $\mathrm{h} / \mathrm{o}$ prenatal or perinatal hypoxicischemic brain injury were excluded.

All the transcranial Doppler examinations were performed in quiet andwakeful patients by the same professional who had been trained to performtranscranial Doppler using the machine Make and Model Make:-Toshiba, Model:

AplioMX, Model SSA-780A with a Toshiba Phased Array Transducer, (Model-PST 30BT $3 \mathrm{MHz}$ ), and following the criteria of the STOP (Stroke Prevention Trial in Sickle Cell Anaemia) study." From this examination, the time-averaged maximum mean velocities weredetermined every $2 \mathrm{~mm}$ along the following arteries: bilateral anterior cerebral, middle cerebral arteries,bilateral ophthalmic arteries and basilar artery using appropriate windows- trans temporal (MCA,ACA).Trans orbital (ophthalmic artery), sub occipital (basilar artery).

TCD was done in a total of 120 children with SCD, comprising of 40 in $\mathrm{HU}$ group and 80 in HU naïve group. It was done in the same condition of temperature and posture (supine) for both the groups. Before transcranial Doppler was done, enough time was given to them until their pulse rate and blood pressure would reach a stable condition. The surrounding environment was quietly calm and this provided the possibility of detecting low amplitude signals with high frequency.

TCD studies have been performed in steady state defined as crises free period extending from at least 3 weeks since last clinical event and 3 months or more since last blood transfusion, before the start of new clinical events. The highest value from the right or left middle cerebral arteries, anterior cerebral artery, ophthalmic arteries, and basilar artery was taken as the time averaged maximum mean velocity for each patient and was used in the data analysis. When the time-averaged maximum mean velocity result was conditional or abnormal, the examinations were repeated until two consecutive abnormal results were obtained. 
As per STOP study velocities were classified as below $[12,13]$.

Normal $-<170 \mathrm{~cm} / \mathrm{sec}$

Conditional - 170-199 cm/sec

High or abnormal - > $200 \mathrm{~cm} / \mathrm{sec}$

Data was compiled in MS excel and checked for its completeness and correctness then it was analyzed by suitable statistical test (chi-square test and Test were applied ) and P-value $<0.05$ was conditional as statistically significant.

\section{Results}

The total number of children enrolled in the present study was 120 , out of which 40 were cases and 80 were controls. Among 120 child patients, there were 83 male children and 37 female children i.e. $69.2 \%$ males and $30.8 \%$ females. Age variations in the series were from 2 years to 14 years, out of which the majority of the patient were in the age group of 6 to 10 years.

A majority of the subjects were vaccinated (94.2\%). $92.5 \%$ among cases and $95 \%$ among controls were completely vaccinated with routine vaccines which were found to be non-significant. In this study Hemoglobin concentration of the majority of the subjects was $5-10 \mathrm{gm}$. Maximum controls (80.0\%) had hemoglobin concentration in 5-10 gm\% range but with none had hemoglobin concentration in > $10 \mathrm{gm} \%$ range. $\mathrm{Hb}$ status was significantly higher in cases than in the control group.
Also, it was found that, in the present study, the most common reason for the previous admission was a vaso-occlusive crisis (case $52.5 \%$ and controls $47.5 \%$ ) followed by the hemolytic crisis (cases $27.5 \%$ and controls 35\%) and blood transfusion (cases $12.5 \%$ and controls $11.2 \%$ ).

In both cases and controls, the mean velocity was in the normal range $(<170 \mathrm{~cm} / \mathrm{sec}$ ) in all patients. Table 1 shows the distribution of the mean velocity of intracranial vessels in case and controls. The mean blood flow velocity of cases was significantly lower than controls $(p<0.05)$. Among cases and controls maximum mean blood flow velocity was found in Left MCA followed by Right MCA. Table 2 shows the comparisons of mean velocities of intracranial vessels between cases and controls. In addition to this, it was also found that there was no significant interhemispheric difference in both group. ( $p$-value more than 0.05).

There were no significant associations between blood flow of Right and Left Side of MCA, ACA and ophthalmic arteries among cases. Table 3 shows the interhemispheric difference in mean velocity in cases and controls.

Table 1. Distribution of mean velocity of intracranial vessels in case and controls.

\begin{tabular}{|l|l|l|l|l|}
\hline & \multicolumn{2}{|c|}{ Cases $\mathrm{n}=\mathbf{4 0}$} & \multicolumn{2}{c|}{ Controls $\mathrm{n}=\mathbf{8 0}$} \\
\hline Mean Velocity $(\mathrm{Cm} / \mathrm{Sec})$ & Number & Percentage & Number & Percentage \\
\hline Normal $(<170)$ & 40 & $100 \%$ & 80 & $100 \%$ \\
\hline Conditional $(170-200)$ & 0 & $0 \%$ & 0 & $0 \%$ \\
\hline High Risk $(>200)$ & 0 & $0 \%$ & 0 & $0 \%$ \\
\hline
\end{tabular}

Table 2. Comparisons of mean velocities of intracranial vessels between cases and controls.

\begin{tabular}{|c|c|c|c|c|c|c|}
\hline & Case/Control & Right MCA & Right ACA & Right ophthalmic artery & Left MCA & Left ACA \\
\hline \multirow[t]{2}{*}{ Case } & Mean & 69.78375 & 61.2065 & 16.03625 & 74.93 & 60.7325 \\
\hline & Std. Deviation & 16.99879 & 19.39805 & 4.13067 & 13.54076 & 15.28812 \\
\hline \multirow[t]{2}{*}{ Control } & Mean & 86.5375 & 70.6045 & 37.94438 & 87.50875 & 73.57125 \\
\hline & Std. Deviation & 24.35198 & 24.42169 & 20.69409 & 23.12311 & 19.59281 \\
\hline \multirow[t]{2}{*}{ Total } & Mean & 80.95292 & 67.47183 & 30.64167 & 83.31583 & 69.29167 \\
\hline & Std. Deviation & 23.47946 & 23.21754 & 19.93601 & 21.22501 & 19.19324 \\
\hline
\end{tabular}

Table 3. The interhemispheric difference in mean velocity in cases and controls

\begin{tabular}{|c|c|c|c|c|c|c|c|c|}
\hline & \multicolumn{4}{|c|}{ Case $n=40$} & \multicolumn{4}{|c|}{ Control $\mathbf{n}=\mathbf{8 0}$} \\
\hline & Right(Mean + Sem) & Left $($ Mean + Sem) & $T$ test & P value & Right (Mean + Sem) & Left (Mean + Sem) & $T$ test & P-value \\
\hline MCA & 69.7838 .68775 & $74.9300+2.14098$ & 1.498 & .138 & $86.5375+2.72263$ & $87.5087+2.58524$ & .259 & .796 \\
\hline$A C A$ & $61.2065+3.06710$ & $60.7325+2.41726$ & .121 & .904 & $70.6045+2.73043$ & $73.5712+2.19054$ & .848 & .398 \\
\hline Ophth & $16.0362+.65312$ & $15.1912+.62619$ & .934 & .353 & $37.9444+2.31367$ & $38.4034+2.24560$ & .142 & .887 \\
\hline
\end{tabular}




\section{Discussion}

In this cross sectional hospital based study, the current observed that the Mean blood flow velocity of the HU group was lower than the HU naïve group. (P-value is less than 0.05), but none of the study subjects (SCA SS) had TCD flow velocity in conditional or high risk range as per STOP criteria. The finding of distribution of the mean velocity of intracranial vessels in the present study differed with the data from a similar study conducted by The Stroke Prevention Trial in Sickle Cell Anaemia (STOP) which reported prevalence of abnormal TCD in $6.72 \%$ of the studied patients (130/1934). Also, Robert Adams, et al 1992 found abnormal velocity $(170 \mathrm{~cm} / \mathrm{sec})$ in 23 out of 190 patients SCD SS (12\%) [14]. Ariane S., et al, 2002 found the mean velocity in the MCA and ACA was $123.7 \mathrm{~cm} / \mathrm{sec}$ and $99.43 \mathrm{~cm} / \mathrm{sec}$ respectively [15]. Another observation made from this study was that the Mean blood flow velocity of the HU group was significantly lower than the HU naïve group. The maximum Mean blood flow velocity was found in Left MCA followed by Right MCA in both the groups. This was supported by the study of Zimmerman SA, et al which also indicated that hydroxyurea can significantly decrease elevated TCD flow velocities, often into the normal range [16]. They suggested a multicenter trial is warranted to determine the efficacy of hydroxyurea for the management of increased TCD values, and ultimately for primary stroke prevention in children with SCA.

In addition, it was also found that there was no significant interhemispheric difference in both groups. ( $p$-value more than 0.05 ). No significant association was found between the blood flow of Rt. and Lt. Side of MCA, ACA and ophthalmic arteries among $\mathrm{HU}$ group and $\mathrm{HU}$ naïve group. This was in consonance with the data from the study conducted by Jesper Bay Hansen et al [17], Mikolaj A. Pawlak, et al [18], Mohammad Ali et al [19] which also showed no significant interhemispheric differences in mean velocity in both the groups.

Mohammad Ali Molavi, Mohammad Reza Aliz, Kamyar Molavi, et alconducted a study and found that in cases who have been treated with hydroxyurea blood flow velocity was less in comparison to those who did not take it which was same as other researches [19].

Melo, et al (In Sergipe), 2005 gathered data on 34 patients with sickle cell anemia, aged less than 18 years, and compared them with 80 controls.
Among the results from the patients, none of them $(0,0 \%)$ presented abnormal time-averaged maximum mean velocity and four (11.7\%) presented conditional results [18\}. Park, et al (In São Paulo), 2006 evaluated 77 patients with sickle cell disease, aged between 2 and 16 years. They found two patients (2.6\%) with abnormal timeaveraged maximum mean velocity and li (14.3\%) with conditional results[19]. Valadi $\mathrm{N}$, et al, 2006 found adults with SCD had a higher mean time averaged maximum mean velocity $(110.9 \pm 25.7 \mathrm{~cm} / \mathrm{s})$ compared with healthy controls $(71.1 \pm 12.0 \mathrm{~cm} / \mathrm{s})$, and the difference is approximately proportional to their anemia [20]. No cases with velocities $>/=200 \mathrm{~cm} / \mathrm{sec}$ were found in this sample.

Margaret T. Lee, et al found mean velocity (MV) of $125.69 \mathrm{~cm} / \mathrm{s}, 123.40$ and $79.44+15.54$ in SCA patients (group1 $=34$ patients) and Controls (group2 $=81$ controls) respectively. MV differences were statistically significant between groups [21].

\section{Conclusion}

The current study concluded that the Mean blood flow velocity in the HU group and HU naïve group was with in the normal range $(<170 \mathrm{~cm} / \mathrm{sec})$, as per STOP criteria. In the current study mean blood flow velocity in patients who were in the HU group was found to be significantly lower than the HU naïve group. However none of the patients under the study groups had TCD flow velocity in the high risk range as per stop criteria. Hence long term follows up studies are needed to conclusively access the effect of hydroxyurea therapy on TCD flow velocity inpatient of SCA SS.

\section{What does the study add to the existing knowledge?}

Long term follows up studies are needed to conclusively access the effect of hydroxyurea therapy on TCD flow velocity inpatient of SCA SS. The patients on hydroxyurea therapy had significantly lower TCD flow velocities as compared to those who did not.

\section{Author's Contributions}

Dr. Sharja Phuljhele, Dr. Prankur Pandey, Dr. Rajesh Banjare conceptualized, designed and analyzed the study, Dr. Prankur Pandey was directly involved in paper drafting, 
Dr. Rajesh Banjare conducted the data collection and helped in analysis and manuscript writing.

Abbreviations : SCD: Sickle cell disease, SCA: Sickle cell anemia, HU: Hydroxyurea, MCA: Middle cerebral artery, ACA: Anterior cerebral artery, STOP: The Stroke Prevention Trial in Sickle cell anemia.

\section{Reference}

01. Lehmann $H$, Cutbush $M$. Sickle-cell trait in southern India. Br Med J. 1952 Feb 23;1(4755)404405. doi: [Article][Crossref][PubMed][Google Scholar]

02. Negi RS. Sickle cell trait in India- A review of known distribution. Bull AnthropolSurv India. 1972;17;439-449. [Crossref][PubMed][Google Scholar]

03. Balgir RS. Genetic epidemiology of the three predominant abnormal haemoglobins in India. J Assoc Physicians India. 1996 Jan;44(1)25-28. [Crossref][PubMed][Google Scholar]

04. Ambekar SS, Phadke MA, Mokashi GD Bankar MP, Khedkar VA, Venkat V, et al. Basutkar DG Pattern of haemoglobinopathies in western Maharashtra. Indian Pediatr. 2001 May;38(5)530534. Available at [Article][Crossref][PubMed] [Google Scholar]

05. Patra PK, Chauhan VS, Khodiar PK, Dalla AR, Serjeant GR. Screening for the sickle cell gene in Chhattisgarh state, India- an approach to a major public health problem. J Community Genet. 2011;2(3)147-151. [Crossref][PubMed][Google Scholar]

06. Chhattisgarh Apip 2012-13 Department Of Women And Child Development. Project Implementation Plan 2012-13, Chhattisgarh. Available at [Article] [Crossref][PubMed][Google Scholar]

07. Shah V, Muley P, Choraria C, Rana P, Kanara D, Markana A. Clinical and hematological profile of sickle cell disease affected children in rural tertiary level hospital. Pediatric Rev-Int J Pediatr Res. 2017;4(3)202-206. Available from: [Article] [Crossref][PubMed][Google Scholar]

08. Kamble M, Chaturvedi P. Epidemiology of sickle cell disease in a rural hospital of central India. Indian Pediatrics. 2000:37(4)391-396. [Crossref] [PubMed][Google Scholar]
09. Adams R McKie V, Nichols F, Carl E, Zhang DL, McKie $K$, Figueroa $R$, et al. The Use of Transcranial Ultrasonography to Predict Stroke in Sickle Cell Disease. N Engl J Med. 1992;326(9)605-610. doi: 10.1056/nejm199202273260905 [PubMed][Google Scholar]

[Crossref]

10. Lowe L, Bulas D. Transcranial Doppler imaging in children- sickle cell screening and beyond. Pediatr Radiol. 2005 Jan;35(1)54-65. doi: 10.1007/s00247004-1257-x [Crossref][PubMed][Google Scholar]

11. Adams RJ, McKie VC, Carl EM, Nichols FT, Perry $R$, Brock $K$, et al. Long-term stroke risk in children with sickle cell disease screened with transcranial doppler. Ann Neurol. 1997;42(5)699-704. doi: 10.1002/ana.410420505[Crossref][PubMed][Google Scholar]

12. Ohene-Frempong $\mathrm{K}$, Weiner SJ, Sleeper LA, Miller ST, Embury S, Moohr JW, et al. Sickle Cell Disease TC Cerebrovascular accidents in sickle cell disease- rates and risk factors. Blood. J Am Soc Hematol. 1998;91(1)288-294 [Crossref][PubMed] [Google Scholar]

13. Lanzkowsky P. Hemolytic Anaemias, Manual of pediatric haematology oncology. 4th ed, Elsevier academic press. 2005;136-198. [Crossref][PubMed] [Google Scholar]

14. Adams R, McKie V, Nichols F, Carl E, Zhang DL, McKie $K$, et al. The use of transcranial ultrasonography to predict stroke in sickle cell disease. New Engl J Med. 1992;326(9)605-610. doi: 10.1056/nejm199202273260905 [PubMed][Google Scholar]

[Crossref]

15. Neish AS, Blews DE, Simms CA, Merritt RK, Spinks AJ. Screening for stroke in sickle cell anemia- comparison of transcranial Doppler imaging and non imaging US techniques. Radiol. 2002;222(3)709-714. doi: 10.1148/radiol.22230 10524 [Crossref][PubMed][Google Scholar]

16. Zimmerman SA, Schultz WH, Burgett S, Mortier NA, Ware RE Zimmerman SA, et al. Hydroxyurea therapy lowers transcranial Doppler flow velocities in children with sickle cell anaemia. Blood. 2007 Aug 1;110(3)1043-1047. doi: 10.1182/blood-2006-11057893 [Crossref][PubMed][Google Scholar]

17. Bay-Hansen J, Ravn T, Knudsen GM. Application of interhemispheric index for transcranial Doppler sonography velocity measurements and evaluation of recording time. Stroke. 1997;28(5)1009-1014. doi: 10.1161/01.str.28.5.1009 [Crossref][PubMed] 
18. Pawlak MA, Krejza J, Rudzinski W, Kwiatkowski $\mathrm{JL}$, Ichord $\mathrm{R}$, Jawad AF, et al. Sickle cell diseaseratio of blood flow velocity of intracranial to extracranial cerebral arteries-initial experience. Radiol. 2009;251(2)525-534. [Crossref][PubMed] [Google Scholar]

19. Molavi $M$, Alizade $M$, Negahi A, Hamedi $Y$, Nazemi $A$, et al. Study of Transcranial Doppler in Children with Sickle-Cell Anaemia in Bandar Abbas Children's Hospital in Period of 2010-2011. AJMPRAsian J Med Pharm Res. 2012;2(1)16-20. Available at [Article][Crossref][PubMed][Google Scholar]

20. Hyder Aragão de Melo, José Augusto S BarretoFilho2, Roberto César P do Prado, Rosana Cipolotti, et al. Transcranial Doppler in Sickle Cell Anaemia Evaluation of brain blood flow parameters in children of Aracaju. Northeast Brazil Arq Neuropsiquiatr. 2008;66(2-B)360-364,360. doi: 10.1590/S0004-282X2008000300015 [Crossref] [PubMed][Google Scholar]
21. Park MVF, Pádua SS, Passos RA, et al. Avaliação do Doppler trans cranianoempacientes com doençafalciforme. Rev Bras Hematol Hemoter. 2006;28(2)14. [Crossref][PubMed][Google Scholar]

22. Valadi N, Silva GS, Bowman LS, Ramsingh D, Vicari P, Massaro AR, Kutlar A, Nichols FT, Adams RJ. Transcranial Doppler ultrasonography in adults with sickle cell disease. Neurol. 2006;67(4)572-574. doi: 10.1212/01.wnl.0000230150.39429.8e [Crossref] [PubMed][Google Scholar]

23. Lee MT, Piomelli $S$, Granger $S$, Miller ST, Harkness S, Brambilla DJ, Adams RJ. Study Investigators, Stroke Prevention Trial in Sickle Cell Anemia (STOP)- extended follow-up and final results. Blood. 2006;108(3)847-852. doi: 10.1182/blood-2005-10-009506 [PubMed][Google Scholar] 